\title{
Altered DNA-binding specificity mutants of EKLF and Spl show that EKLF is an activator of the $\beta$-globin locus control region in vivo
}

\author{
Nynke Gillemans, Rita Tewari, Fokke Lindeboom, Robbert Rottier, Ton de Wit, Mark Wijgerde, \\ Frank Grosveld, ${ }^{1}$ and Sjaak Philipsen
}

Erasmus University Rotterdam, Medical Genetics Center-Department of Cell Biology, 3000 DR Rotterdam, The $\mathrm{N}$ etherlands

\begin{abstract}
The locus control region of the $\beta$-globin cluster contains five DNase I hypersensitive sites (5'HS1-5) required for locus activation. 5' HS3 contains six G-rich motifs that are essential for its activity. Members of a protein family, characterized by three zinc fingers highly homologous to those found in transcription factor Spl, interact with these motifs. Because point mutagenesis cannot distinguish between family members, it is not known which protein activates $5^{\prime}$ HS3. We show that the function of such closely related proteins can be distinguished in vivo by matching point mutations in $5^{\prime} \mathrm{HS3}$ with amino acid changes in the zinc fingers of Spl and EKLF. Testing their activity in transgenic mice shows that EKLF is a direct activator of $5^{\prime} \mathbf{H S 3}$.
\end{abstract}

[Key Words: Zinc fingers; binding site specificity; locus control region; Sp1; EKLF; transcriptional activation; globin]

Received June 5, 1998; revised version accepted July 29, 1998.

The human $\beta$-globin cluster contains five structural genes in the order $5^{\prime}-\epsilon$ (embryonic) $-\mathrm{G} \gamma-\mathrm{A} \gamma$ (fetal $)-\delta-\beta$ (adult)- $3^{\prime}$. Expression of these genes is completely dependent on the presence of the locus control region (LCR), a $20-\mathrm{kb}$ sequence located upstream of the $\epsilon$-gl obin gene (for review, see Grosveld et al. 1993). The LCR is characterized by the presence of five erythroid-specific DN ase I hypersensitive sites, termed 5'HS1-5. The activity of the LCR resides in the hypersensitive areas (Grosveld et al. 1993). Our previous work has focused on the functional dissection of 5' HS3 of the LCR. It is the strongest activator when single hypersensitive sites are linked to the $\beta$-globin gene (Fraser et al. 1990), and it appears to have a dominant chromatin-opening activity (Ellis et al . 1996). The 225-bp core fragment coinciding with the hypersensitive site retains the essential properties of 5' HS3 (Philipsen et al. 1990). This core contains three footprinted binding sites for the erythroid-specific transcription factor GATA-1, alternated with three footprinted G-rich sequences or $G$ boxes (Philipsen et al. 1990; Strauss and Orkin 1992). The smal lest fragment capable of activating a $\beta$-globin gene in transgenic mice consists of footprints 1-3 (fp 1-3) of the core fragment (Philipsen et al. 1993). Fp 1 and 3 are GATA-1 binding sites, and fp 2 contains $\mathrm{G}$ boxes that are bound by multiple factors.

${ }^{1}$ Corresponding author.

E-MAIL vangeest@chl.fggeur.nl; FAX 31-10-436 0225.
Point mutations in $\mathrm{fp} 1$ and 3 have shown that intactness of these sequences is absolutely essential for activity. From this, we concluded that GATA-1 binds to fp 1 and 3 in vivo. In contrast, point mutations abolishing binding of single factors to the $G$ boxes of fp 2 could not be designed (Philipsen et al. 1993). The $G$ boxes are bound by members of a transcription factor family characterized by the presence of three zinc fingers highly homologous to those found in Spl. The Spl family includes ubi quitously expressed proteins like Spl (Kadonaga et al. 1987), Sp3 (Hagen et al. 1992; Kingsley and Winoto 1992), basic transcription element binding protein (BTEBs; Imataka et al. 1992) and basic Krüppel-like factor (BKLF; Crossl ey et al. 1996), and tissue-restricted factors like gut-enriched Krüppel-like factor (GKLF; Shiel ds et al . 1996), lung Krüppel-like factor (LKLF; A nderson et al. 1995), and erythroid Krüppel-like factor (EKLF; M iller and Bieker 1993). Moreover, a large number of Spl-like zinc finger domains can be found in the expressed sequence tag (EST) databases. Fp 2 is bound in vitro by Spl, Sp3, BKLF, EKLF, and other as yet uncharacterized family members, present in erythroid nuclear extracts (Philipsen et al. 1993; N. Gillemans, unpubl.). This plethora of transcription factors precludes a straightforward interpretation of the relationship between binding sites and activators, and thus it is not known which protein binds to fp 2 in vivo.

The apparent redundancy of transcription factors 
presents a general problem in the interpretation of gene expression data. The analysis of knockout mice is a first step toward the sol ution of this problem (e.g., N uez et al. 1995; Perkins et al . 1995; M arin et al. 1997; Tewari et al. 1998), but this approach can only provide indirect answers. Pioneering work in Drosophila has established that a DN A-binding specificity mutant can be used as a tool to demonstrate direct interaction of a transcription factor and a DN A target site in a multicellular organism (Schier and Gehring 1992). In this paper we have applied this approach to mice, utilizing the minimal fragment of $5^{\prime} \mathrm{HS} 3$ to test the role of putative activator proteins (Sp1 and EKLF) directly. First, we mutated the $G$ boxes in $\mathrm{fp} 2$ so they no longer bind Spl family members in vitro. Second, we designed zinc fingers recognizing the mutated sequence in fp 2 . We then tested the capacity of the engineered factors ( $\mathrm{mSpl}$ and $\mathrm{mEKLF}$ ) to activate the mutant fp 2 construct in transgenic mice. The results show that EKLF but not Spl activates fp 2 of 5' HS3, and we conclude that EKLF plays a very specific role in the activity of $5^{\prime} \mathrm{HS} 3$ and in the activation of the $\beta$-globin locus.

\section{Results}

\section{Experimental strategy}

We have used human $\beta$-globin gene activation by the minimal fragment of $5^{\prime} \mathrm{HS} 3$ as the experimental system (Fig. 1A). The functional importance of the GATA-1 sites in fp 1 and 3 and the $G$ boxes in fp 2 (Fig. 1B) has been anal yzed extensively in transgenic mice (Philipsen et al. 1993). The results of these experiments show that all three footprinted sequences are requi red for activation of a linked $\beta$-globin gene. Spl family members recognize a 9-bp sequence GGG GT / CG GGG (Letovsky and Dynan 1989) and thus it could be predicted that fp 2 contains two overlapping binding sites, in addition to potential weaker binding sites (Fig. 1B, wild type). To minimize the complexity of $\mathrm{fp} 2$, we first determined whether one binding site would suffice for activation. Two mutants with only one binding site (Fig. 1B, 5' and $3^{\prime}$ ) were made by disrupting every other potential binding site by $\mathrm{G} \rightarrow \mathrm{T}$ transversions (Philipsen et al. 1993). These mutants were placed in their natural context between $\mathrm{fp} 1$ and 3 and the resulting fragments were tested for their capacity to activate the $\beta$-gl obin gene in transgenic mice. Founder fetuses were dissected at 13.5 days of gestation (E13.5), and DN A was prepared from the head, yolk sac, and placenta to determine the transgene copy number and to check for mosaicism (Philipsen et al. 1993). RN A was isolated from the livers of nonmosaic transgenic fetuses, and the level of human $\beta$-gl obin mRN A was quantitated with S1 nuclease protection analysis using the level of the endogenous $\beta$-major mRNA as an internal control (Philipsen et al. 1993). The expression level per transgene copy was set at 100 for the wild-type fp 1-3 construct (Fig. 1B). The constructs with only one $G$ box in fp 2 are expressed at approximately twofold lower levels than those observed with the wild-type fp 1-3 con-
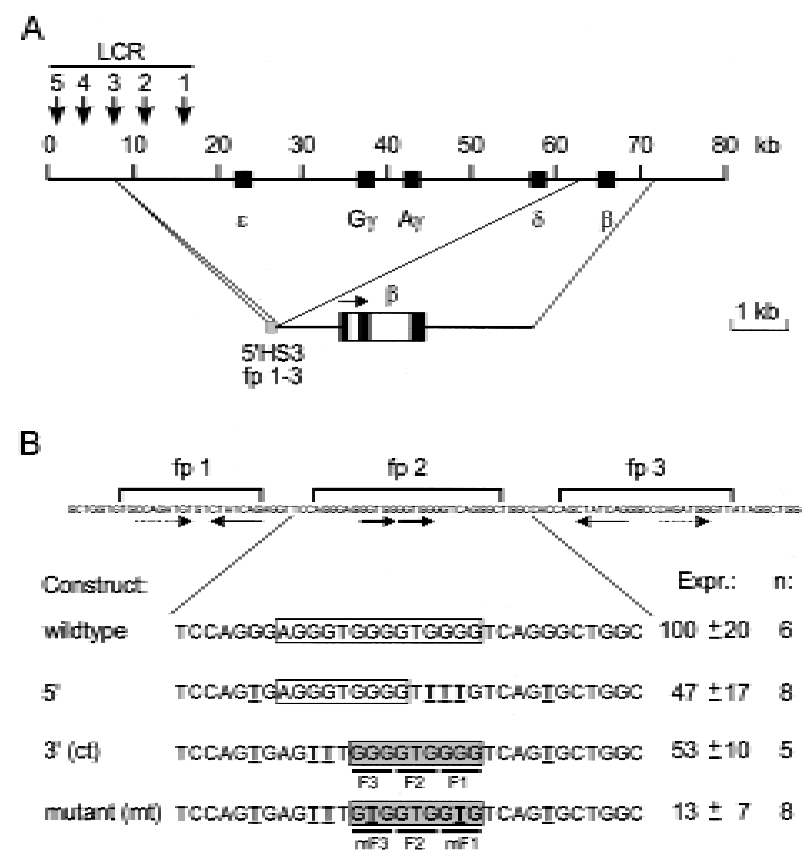

Figure 1. Activity of the fp 1-3 fragment 5 'HS3 of the human $\beta$-globin LCR in transgenic mice. (A) Schematic drawing of the human $\beta$-globin locus. The hypersensitive sites of the LCR are indicated by downward arrows, the genes by solid boxes (top). The activity of fp 1-3 of 5'HS3 was analyzed in transgenic mice using the Hpal-EcoRV fragment of the $\beta$-globin gene as the reporter gene (bottom). (B) Quantitation of the expression of $\mathrm{fp}$ 1-3 constructs in transgenic mice. The sequence of the fp 1-3 area is shown (top). Strong GATA-1 binding sites are underlined with thin arrows; weak GATA-1 binding sites with broken arrows (Philipsen et al. 1993), the two G-rich motifs in fp 2 are underlined with bold arrows. Permutations of $\mathrm{fp} 2$ analyzed in transgenic founder fetuses are shown below. The G-rich motifs are boxed. Point mutations introduced are in boldface and underlined. A shaded box highlights the mutant binding site. $\mathrm{N}$ ucleotides interacting with the zinc fingers of Spl family members are underscored with solid lines (F1, F2, F3), as are nucl eotides in the mutant binding site interacting with the mutant zinc fingers ( $\mathrm{mF} 1, \mathrm{mF} 3$ ). Expression levels (Expr.) are given with standard deviations, and the number of independent transgenics analyzed is indicated (n).

struct. Thus, we conclude that each $\mathrm{G}$ box contributes to the activity of $\mathrm{fp} \mathrm{1-3.} \mathrm{Because} \mathrm{the} 3$ ' sequence has the best match with the Spl consensus binding site (Letovsky and Dynan 1989), we concentrated on this motif. For reasons of clarity, we will refer to this permutation of fp 2 as control (ct in Fig. 1B), hereafter.

The zinc fingers of Spl family members are structurally closely related to those of the Zif268 protein ( $\mathrm{Na}$ rayan et al. 1997; Sjottem et al. 1997). From the crystal structure of the DNA-binding domain of Zif268 it is known that one zinc finger occupies $3 \mathrm{bp}$ in the recognition sequence (Pavletich and Pabo 1991). We therefore assumed that fingers 1 and 3 recognize the triplet GGG, and finger 2 the triplet GTG in fp 2 (Fig. 1B). Hence, mutation of GGG to GTG triplets should interfere with recognition by fingers 1 and 3 of Spl family members. We tested the activity of this fp 2 mutant in transgenic 
mice. The analysis of eight founder fetuses shows that the fp 2 mutant results in a further fourfold reduction of $\beta$-gl obin reporter expression as compared with control fp 2 (Fig. 1B). These data are consistent with earlier observations in transgenic mice containing more drastic mutations in fp 2 (Philipsen et al. 1993). Thus, we conclude that the lower expression level is due to decreased binding of an activator protein to the mutant fp 2 sequence and that the fp 2 mutant could be used to test the transcriptional effect of modified activator proteins engineered to bind specifically to this sequence.

Construction of transcription factors with altered DNA-binding site specificity

We set out to change the DNA-binding site specificity of two candidate activators of 5'HS3: Sp1, the ubiquitously expressed archetypal transcription factor, and EKLF, the only erythroid-specific Sp1 family member described to date. The fp 2 mutant contains a 9-bp sequence consisting of three GT G tripl ets (Fig. 1B). In wild-type Spl family members, zinc finger 2 recogni zes this sequence (Li et al. 1991; Feng et al. 1994; $N$ arayan et al. 1997; Sjottem et al. 1997). Thus, if we would change the specificity of fingers 1 and 3 of EKLF and Spl to that of finger 2, we should obtain proteins that interact specifically with the fp 2 mutant. However, such changes may have unexpected consequences. A simple triplication of finger 2 of Spl binds to such a sequence al beit with reduced affinity (Desjarlais and Berg 1993), which might be due to structural determinants provided by fingers 1 and 3, and/or the spacer amino aci ds between the fingers (Jacobs 1992; Choo and Klug 1993; Isal an et al. 1997). In addition, zinc fingers are involved in protein-protein interactions (Perkins et al. 1994; M erika and Orkin 1995) and notably, the interactions with GATA-1 are of di rect relevance to this work (Merika and Orkin 1995). Therefore, we substituted the minimum number of amino acids in the recognition helices of fingers 1 and 3 to make their DN Abinding specificity identical to that of finger 2 of Sp1 (Pavletich and Pabo 1991; N arayan et al. 1997; Sjottem et al. 1997). N o other changes to the zinc finger domains of Sp1 and EKLF were made to preserve presumptive functions other than di rect DN A recognition (Fig. 2A; mSpl and $\mathrm{mEKLF}$ ).

The mutant transcription factors are transcriptional activators

First, we determined whether mEKLF and mSpl would be active as transcriptional activators in a binding site-

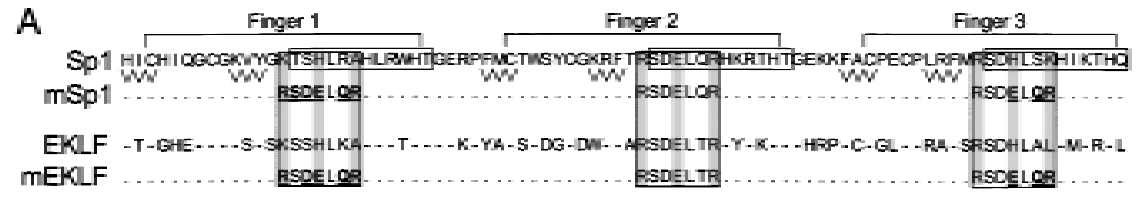

B
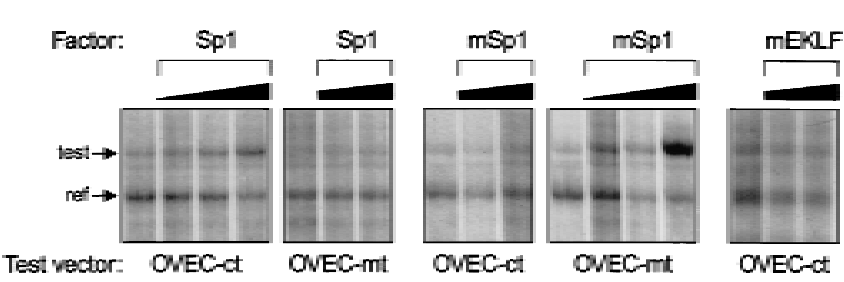

ONEC-ct

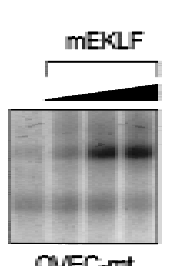

ONEC-mt

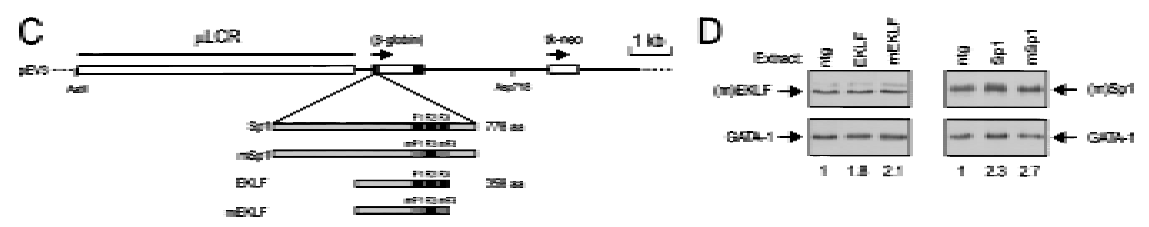

Figure 2. Sp1 family members with novel binding site specificity. (A) The amino acid sequence of the three zinc fingers of $\mathrm{Sp} 1$ is shown (top). $\beta$-Sheets are shown as zigzag lines and $\alpha$-helices are boxed (adapted from Pavletich and Pabo 1991). Large rectangles include all of the amino acids that are known to make base contacts; the shading indicates residues that are thought to be particularly important for binding site recognition. Amino acid substitutions in fingers 1 and 3 of Sp1 are underlined and bold (mSpl). The amino acid sequence of the EKLF zinc fingers is shown below. Residues identical to those found in Spl are indicated by dashes. Amino acid substitutions in fingers 1 and 3 of EKLF are underlined and bold (mEKLF). Unchanged residues are indicated by dots. (B) $\mathrm{mSpl}$ and mEKLF are functional transcriptional activators. CHO cells were transfected with 3 $\mu \mathrm{g}$ of OVEC test vector containing either the control (OVEC-ct) or the mutant (OVEC-mt) binding site, $0.15 \mu \mathrm{g}$ of OVEC reference vector and $0.1,0.5$, or $2 \mu \mathrm{g}$ of the indicated pRc/CMV expression vector (factor). After $72 \mathrm{hr}$, the cel Is were harvested and RN A synthesized from the OVEC vectors was analyzed by the RN ase protection assay (Westin et al. 1987). The RNA probe detects the signals of both the reference and test vector; these are indicated by arrows (ref and test, respectively). (C) Schematic drawing of the pEV3 vector used to express transcription factors in erythroid cells. The cDN As encoding $\mathrm{Spl}$, mSpl, EKLF, and mEKLF were inserted in the first exon of a modified $\beta$-globin gene. Erythroid-specific expression is driven by a 6.5-kb version of the LCR ( $\mu \mathrm{LCR}$; Tal bot et al. 1989). The tk-neo gene is used for selection of stably transfected M EL cells. The Aatll and Asp718 restriction sites were used to isol ate the microinjection fragment for transgenesis. (D) Western blot analysis of transcription factor expression in transgenic mice. N uclear protein extracts were made of E13.5 livers with the indicated pEV transgene; (ntg) N ontransgenic fetal liver. Twenty micrograms of protein was used for Western blotting. The blots were probed with anti-EKLF (top left) or anti-Sp1 rabbit polyclonal antibodies (top right). As a loading control, they were reprobed with an anti-GATA-1 rat monoclonal antibody (bottom). (Bottom) Relative levels of EKLF and Spl as determined by densitometric scanning of the autoradiographs and normalized to the GATA-1 loading control (ntg=1). 
dependent manner. We inserted the control and mutant binding site 20 bp upstream of the TATA box in the promoter of the OVEC test vector (Westin et al . 1987) to assess the capacity of the factors to act as classical transcriptional transactivators. The cDNAs encoding the factors were cloned in the expression vector $\mathrm{pRc/CMV}$. These constructs were cotransfected in $\mathrm{CHO}$ cells with the OVEC test vectors and the OVEC-REF vector, which serves as an internal control for transfection efficiency. RNA was isolated $72 \mathrm{hr}$ after transfection, and the RN A synthesized from the OVEC test- and OVEC-REF vectors was quantitated by RN ase protection anal ysis (Westin et al . 1987). This shows that increasing the amount of mSpl stimulates transcription of the OVEC vector with the mutant binding site (OVEC-mt; Fig. 2B) but not of the OVEC vector with the control binding site (OVEC-ct; Fig. 2B). On the contrary, Spl has no effect on transcripti on of the OVEC-mt construct but stimulates transcription of the OVEC-ct construct (Fig. 2B). Transactivation by $\mathrm{Spl}$ appears to be less effective than that observed with mSpl (Fig. 2B), most likely because of competition with transcriptional repressors like Sp3 for binding to the control sequence but not the mutant sequence $(\mathrm{Ha}-$ gen et al. 1994). A very similar result is obtained with mEKLF transactivation (Fig. 2B; data not shown).

We conclude that the altered DN A-binding specificity mutants of EKLF and Spl are functional transcriptional activators that can stimulate transcription through the mutant fp 2 sequence in vivo.
Erythroid-specific expression and DNA-binding properties of the transcription factors

To express the transcription factors in red cells, we cloned cDN As encoding the wild-type and mutant proteins in the erythroid-specific expression vector pEV3 (N eedham et al . 1992), resulting in Sp1-pEV, mSpl-pEV, EKLF-pEV, and mEKLF-pEV (Fig. 2C). M urine erythroleukaemia (MEL) cel Is were stably transfected with these constructs to check for the expression and DN A-binding properties of the transgene-derived transcription factors (Fig. 3A; data not shown); they were then used to generate transgenic mice. For each construct, one transgenic line was analyzed further; these lines will be referred to as Spl-pEV, mSpl-pEV, EKLF-pEV, and mEKLF-pEV.

The expression levels of transgene-derived transcription factors were assessed by Western blot analysis of E13.5 fetal liver extracts. The blots were probed with rabbit polyclonal antisera directed against EKLF or Spl. The epitopes recognized by these antibodies are aminoterminal to the zinc finger domains and they therefore detect both the wild-type and mutant transcription factors. As a loading control, the blots were reprobed with a rat monoclonal antibody specific for the erythroid-specific transcription factor GATA-1. The results show that the expression levels of the transgene-derived transcription factors are comparable to those of the endogenous factors, as we observe a moderate (approximately twofold) increase of the signals in the transgenic samples,
Figure 3. Gel retardation analysis of $\mathrm{Spl}$ family members binding to the mutant $\mathrm{fp} 2$ binding site. (A) Extracts were made from MEL cells transfected with pEV3, EKLF-, Sp1-, and mSp1-pEV. In lanes 1 and 2, $2 \mu \mathrm{g}$ of extract was incubated with the control $\mathrm{fp} 2$ probe (ct; see Fig. 1). In lanes 3 and 4, $4 \mu \mathrm{g}$ of extract was used. These reactions contained a fivefold molar excess of Spl competitor oligonucleotide to reduce the background caused by $\mathrm{Spl}$ family members that bind more avidly to GC than to GT boxes. The binding reactions were separated on a $4 \%$ PAA/0.5 $\times$ TBE gel. The positions of bands corresponding to Sp1, Sp3, BKLF, and EKLF are indicated (see Crossley et al. 1996; M arin et al. 1997). (B) Extracts were made from fetal livers transgenic for Sp1-, mSp1-, or mEKLFpEV. In lanes 1-6, $10 \mu \mathrm{g}$ of extract was incubated with the mutant fp 2 probe ( $\mathrm{mt}$; see Fig. 1). In lanes 7-12, $2 \mu \mathrm{g}$ of extract was used, and in lanes 13-17, $5 \mu \mathrm{g}$ of extract was added to the reactions. In addition, the reactions contained a 50-fold molar excess of cold mutant fp 2 double-stranded competitor ol igonucleotide ( $\mathrm{mt} \mathrm{fp2;} \mathrm{lanes} \mathrm{2,8,14)} \mathrm{or} \mathrm{control} \mathrm{fp2} \mathrm{control} \mathrm{competitor} \mathrm{(ct} \mathrm{fp2;} \mathrm{lanes} \mathrm{3,9),} \mathrm{or} \mathrm{antibodies}$ directed against Sp3 ( $\alpha$ Sp3; Ianes 4,10,15), EKLF ( $\alpha$ EKLF; Ianes 5,11,16) and Sp1 ( $\alpha$ Sp1; lanes 6,12,17). The positions of mEKLF, mSp1, and the free probe are indicated by arrows; a vertical bar denotes the positions of supershifts after the addition of antibody. Apparent degradation products of $\mathrm{mEKLF}$ are marked with an asterisk. (C) Binding specificity of $\mathrm{mSpl}$ and $\mathrm{mEKLF}$ to the mutant fp 2 sequence. Two micrograms of mSpl-pEV or $4 \mu \mathrm{g}$ of mEKLF-pEV fetal liver extract was incubated with the mutant fp 2 probe in the presence of increasing amounts of cold competitor ol igonucl eotides. (Lane 1) N o competitor added; (lanes 2-4) 2-, 10-, and 50-fold mol ar excess of mutant fp 2 competitor; (lanes 5-7) 2-, 10-, and 50-fold molar excess of control fp 2 competitor, respectively.
A

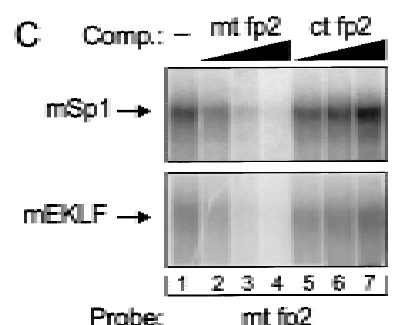

Probe: $\mathrm{mt}$ fip
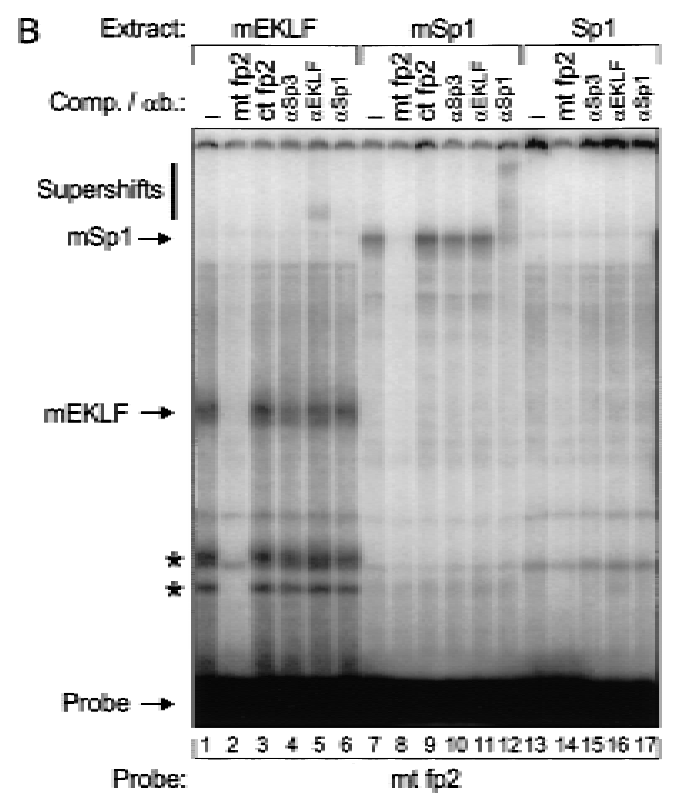
relative to the GATA-1 control (Fig. 2D). We conclude that the transgene-derived transcription factors are expressed at physiological levels, thus allowing comparison of the biological effects of these factors.

Protein extracts derived from transfected MEL cells and E13.5 transgenic livers were used for gel retardation anal ysis with oligonucleotide probes containing the control or the mutant fp 2 sequence. Transfected MEL cell extracts show that transgene-derived Sp1 and EKLF proteins bind to the control fp 2 sequence (Fig. 3A); this could not be demonstrated in fetal liver extracts because of the large background caused by other proteins present in these extracts (data not shown).

Very little, if any, specific binding to the mutant fp 2 ol igonucleotide is observed with extracts from Sp1-pEV fetal livers (Fig. 3B), or with extracts from EKLF-pEV and nontransgenic livers (data not shown). Thus, Sp1 family members do not appear to interact efficiently with the mutant sequence, in agreement with the functional data obtained in transgenic mice (Fig. 1B) and CHO cells (Fig. $2 \mathrm{~B})$. In contrast, transgene-derived $\mathrm{mSp} 1$ and $\mathrm{mEKLF}$ proteins do interact with the mutant fp 2 sequence. The specificity of these interactions is demonstrated by the addition of competitor oligonucleotides and antibodies to the reactions (Fig. 3B,C). Thus, we conclude that mEKLF and mSpl bind specifically to the mutant fp 2 sequence in vitro and not to the control fp 2 sequence, whereas the opposite is true for wild-type EKLF and Spl.

\section{Functional analysis in transgenic mice}

To analyze the effect of EKLF and Spl on the activity of fp 1-3 constructs in transgenic mice, we generated reporter mice with the control or the mutant fp 1-3 fragment driving expression of the human $\beta$-gl obin gene (see Fig. 1). For each construct, two independent lines were established. These lines were crossed with the Sp1-pEV, mSpl-pEV, EKLF-pEV, and mEKLF-pEV lines, and the effect of transgene-derived transcription factors on human $\beta$-gl obin gene expression was determined by quantitative S1 nuclease protection analysis (Fig. 4; Table 1). The level of mouse $\alpha$-globin mRN A was used as an internal control. Expression of the control reporter gene is not altered by the presence of Spl-pEV, mSp1-pEV, EKLF-pEV, or mEKLF-pEV transgenes. Thus, the transgene-derived transcription factors have no influence on the control reporter gene, excluding the possibility of a dominant effect on reporter gene expression. In contrast, the expression levels of the mutant reporter gene are affected by mEKLF, but not by Spl, $\mathrm{mSpl}$, and EKLF. This demonstrates that the observed differences are dependent on the altered zinc finger domains of mEKLF and that the effect is specific to EKLF, as mSpl has no influence on the mutant reporter gene. Expression of the mutant reporter gene is increased threefold in the presence of $m E K L F$, approaching the level observed with the control construct (Fig. 4; Table 1). From this we conclude that EKLF directly activates 5'HS3 by binding to fp 2 in vivo. Interestingly, the $\mathrm{mSpl}$ protein has no effect on $\beta$-globin gene expression through fp 2 of $5^{\prime} \mathrm{HS} 3$, even

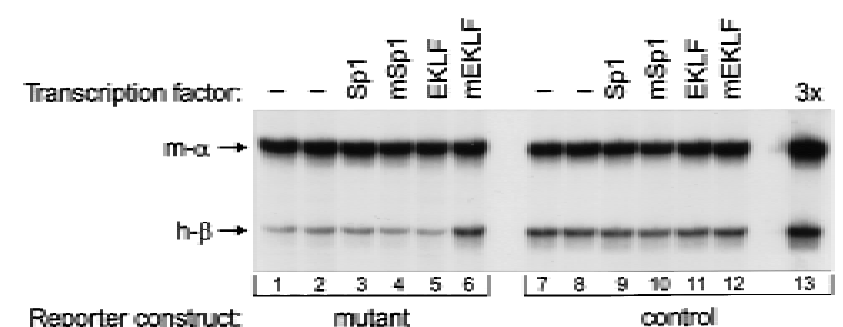

Figure 4. Quantitative S1 nuclease protection assay of human $\beta$-globin transgene expression. RNA was isolated from E13.5 fetal livers containing the mutant or the control $\beta$-globin reporter construct and the Sp1-, mSp1-, EKLF-, or mEKLF-pEV transgenes as indicated. One microgram of RNA was used for the S1 nuclease protection assay with probes detecting endogenous mouse $\alpha$-globin mRNA $(\mathrm{m}-\alpha)$ and human $\beta$-globin mRNA (h- $\beta$ ). An increased level of human $\beta$-globin mRNA is only observed for the mutant reporter in the presence of mEKLF (lane 6); no changes are found in any of the other combinations. Lane 13 contains $3 \mu \mathrm{g}$ of the RNA sample used in lane 7 to demonstrate probe excess.

though it is a functional activator when the mutant binding site is placed in the context of the promoter of the OVEC vector (Fig. 2B). Thus, it appears that the specific combination of GATA-1 bound at $\mathrm{fp} 1$ and 3 and EKLF bound at fp 2 is required for the activity of $5^{\prime} \mathrm{HS} 3$ in erythroid cells.

\section{Analysis of reporter gene expression at the single cell level}

The S1 nuclease protection assay described above provides a quantitative measurement of reporter gene expression in populations of cells. Therefore, the reporter gene might be expressed at a high level in a subset of the cells and not in the remaining cells. In this scenario, mEKLF would act by increasing the fraction of cells expressing the mutant reporter gene. Alternatively, the reporter gene might be expressed in the large majority of erythroid cells, in which case mEKLF could exert its effect by increasing the rate and/or the duration of active transcription of the mutant reporter gene (Milot et al.

Table 1. Expression levels of human $\beta$-globin mRNA in E13.5 fetal liver cells of reporter/transcription factor transgenic lines

\begin{tabular}{lcccc}
\hline & \multicolumn{4}{c}{ Reporter transgene (copy no.) } \\
\cline { 2 - 5 } $\begin{array}{l}\text { pEV } \\
\text { transgene }\end{array}$ & $\begin{array}{c}\text { control } \\
\text { line 1 (5) }\end{array}$ & $\begin{array}{c}\text { control } \\
\text { line 2 (17) }\end{array}$ & $\begin{array}{c}\text { mutant } \\
\text { line 1 (7) }\end{array}$ & $\begin{array}{c}\text { mutant } \\
\text { line 2 (4) }\end{array}$ \\
\hline N one & 56 & 40 & 15 & 11 \\
Sp1 & 55 & 42 & 14 & 10 \\
mSp1 & 55 & 42 & 16 & 11 \\
EKLF & 55 & 40 & 15 & 11 \\
mEKLF & 54 & 41 & 43 & 32 \\
\hline
\end{tabular}

Expression of the reporter genes was calculated as the ratio of human $\beta$-globin to mouse $\alpha$-globin signals, corrected for transgene copy number, and normal ized to the expression level of the wild-type fp 1-3 construct (=100; see Fig. 1B). 
1996b). To distinguish between these possibilities, we anal yzed reporter gene expression at the single cell level by primary transcript in situ hybridization (Wijgerde et al. 1995). Oligonucleotide probes detecting nuclear transcription spots of the endogenous $\alpha$-globin genes were used to determine the number of erythroid cells (Tewari et al. 1996). Human $\beta$-globin nuclear transcription signals were visualized with four oligonucleotides derived from intron 1; as two of these probes overlap partially with exon sequences, cytoplasmic $\beta$-globin mRN A can also be detected (Dillon et al. 1997). The presence of cytoplasmic mRN A shows that a cell has expressed the transgene at some point in time, whereas the presence of nuclear precursor RNA at the site of transcription is indicative of active transcription because precursor RN As are rapi dl y processed (Wijgerde et al. 1995). The results of this analysis are summarized in Figure 5 and Table 2.

Cells expressing mEKLF show a three to fourfold increased number of nuclei with transcriptional foci of the mutant reporter gene. Moreover, the cytoplasm of the cells shows a more intense red staining than cells with just the mutant reporter construct, reflecting the increased amounts of human $\beta$-globin mRNA in the presence of mEKLF. Human $\beta$-globin signals are not affected if $\mathrm{mSpl}$ is expressed in these cells, in agreement with the S1 nuclease analysis. All cells with the control reporter gene contain $\beta$-globin mRNA in the cytoplasm, as do cells with the mutant reporter containing mEKLF. Expression of any of the transcription factors has no effect on the control reporter gene, nor does expression of Spl or EKLF have any effect on the mutant reporter gene, in agreement with the S1 nuclease data.

Thus, the in situ hybri dization anal ysis shows that the fp 1-3 reporter transgenic lines used in this study do not show classical position effect variegation. Such effects can be observed when LCR mutants in the context of the 70-kb $\beta$-globin locus are integrated in heterochromatic regions (Milot et al. 1996b). The fact that we observe primary transcription signals in only part of the cells shows that transcription of the reporter genes is discontinuous. Importantly, mEKLF appears to activate the mutant reporter gene in all cells because the cytoplasmic staining increases in all cells (Fig. 5).
Table 2. Primary transcript in situ hybridization of E13.5 fetal liver cells from reporter/transcription factor transgenic lines

\begin{tabular}{lcccc}
\hline & \multicolumn{4}{c}{ Reporter transgene (copy no.) } \\
\cline { 2 - 5 } $\begin{array}{l}\text { pEV } \\
\text { transgene }\end{array}$ & $\begin{array}{c}\text { control } \\
\text { line 1 (5) }\end{array}$ & $\begin{array}{c}\text { control } \\
\text { line 2 (17) }\end{array}$ & $\begin{array}{c}\text { mutant } \\
\text { line 1 (7) }\end{array}$ & $\begin{array}{c}\text { mutant } \\
\text { line 2 (4) }\end{array}$ \\
\hline None & 57 & 86 & 13 & 7 \\
Sp1 & 59 & N.D. & 14 & 8 \\
mSp1 & 55 & N.D. & 12 & 6 \\
EKLF & 56 & N.D. & 14 & 7 \\
mEKLF & 55 & N.D. & 39 & 23 \\
\hline
\end{tabular}

The percentage of cells with human $\beta$-globin transcription signals was calculated from at least 300 cells with $\alpha$-globin transcription signals (see Fig. 5) for each data point. The error margin was $<10 \%$.

\section{DNase I hypersensitivity analysis}

The core fragments of the LCR coincide with strong, erythroid-specific DN ase I hypersensitive sites. In E13.5 liver cells of the reporter lines a hypersensitive site is found at the control fp 1-3 sequence, whereas a weaker hypersensitive site is found at the mutant fp 1-3 sequence (data not shown). Thus, we asked whether binding of mEKLF to the mutant fp 1-3 sequence would result in increased DNase I hypersensitivity. To investigate this, nuclei isol ated from transgenic E13.5 liver cells were subjected to a DN ase I fade-out analysis (see Ellis et al. 1996). Purified DN A of these DN ase I series was digested with $\mathrm{Ncol}$ and Southern blotted (Fig. 6). In the absence of mEKLF, a weak hypersensitive site is detectable at the mutant fp 1-3 area (Fig. 6B, mutant); hypersensitivity is increased modestly in the compound transgenic (Fig. 6B, mutant + mEKLF). As a control for DN ase I digestion, the same bl ot was stripped and rehybridized with a probe detecting a $0.85-\mathrm{kb}$ fragment of the mouse $\alpha_{1}$-globin gene, as DN ase I sensitivity of this gene should not be affected by mEKLF (Fig. 6B, bottom). Quantitation of the signals in the hypersensitive site area relative to the corresponding mouse $\alpha_{1}$-gl obin signals indi cates that hypersensitivity is increased two- to threefold in the presence of mEKLF (Fig. 6C). We conclude from these
Figure 5. Primary transcript in situ hybridization detecting human $\beta$-globin and mouse $\alpha$-globin transcription. E13.5 fetal liver cells with the indicated transgene makeup (see al so Fig. 4) were disrupted in PBS, spotted on polylysine-coated slides, fixed, and subjected to primary transcript in situ hybridization with two sets of oligonucleotide probes detecting mouse $\alpha$-globin (green) and human $\beta$-globin (red) nuclear transcription signals. The probes for human $\beta$-globin also detect cytoplasmic mRNA; this is particularly evident in the mutant reporter/mEKLF and the control reporter cells. Representative examples of 20 cells are shown for each transgene combination.

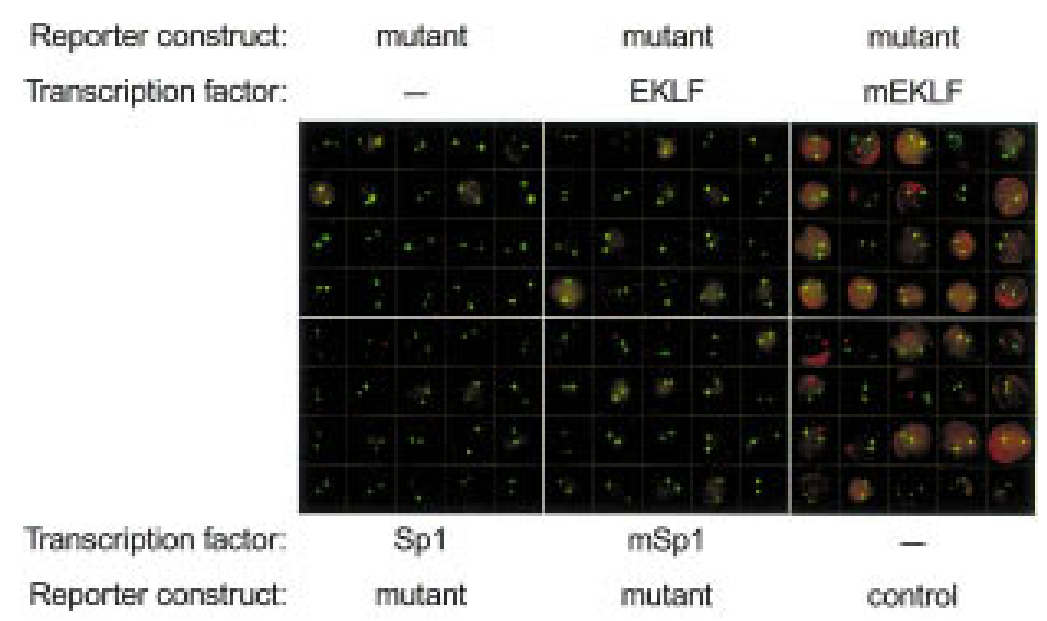


EKLF but not Spl is an activator of the LCR

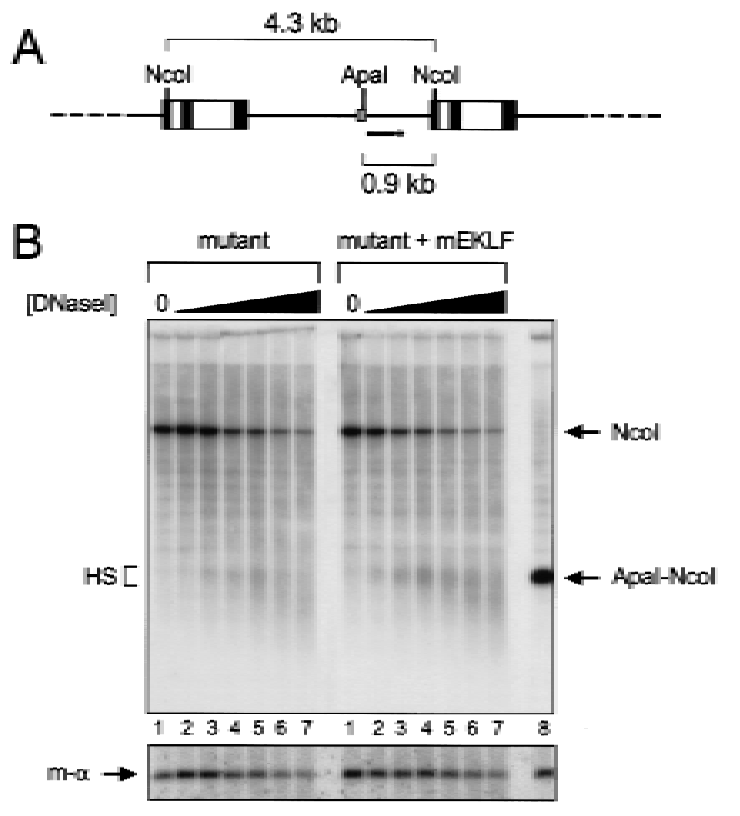

C

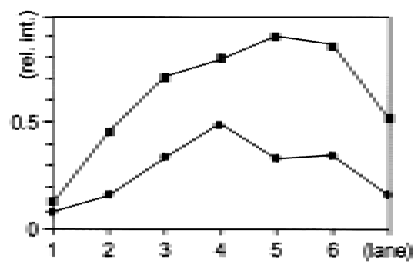

Figure 6. Hypersensitive site formation at the mutant $\mathrm{fp} 1-3$ sequence in the presence of mEKLF. (A) Schematic drawing of the mutant reporter transgene array and the strategy used to detect hypersensitivity at $\mathrm{fp} 1-3$. The $\mathrm{H}$ pal-Accl probe does not detect the mEKLF-pEV transgene (N eedham et al. 1992). The probe (bar with asterisk) hybridizes to the $4.3-\mathrm{kb} \mathrm{Ncol}$ repeat fragment of the mutant reporter gene. The $0.9-\mathrm{kb}$ Apal- $\mathrm{Ncol}$ fragment marks the position of the hypersensitive site (see $B$ ). (Other details are as for Fig. 1.) (B) Southern bl ot analysis of the hypersensitive site at the mutant $\mathrm{fp} 1-3$ sequence. $\mathrm{N}$ uclei were isolated from E13.5 fetal livers from mutant reporter and mutant reporter/mEKLF-pEV transgenics as indicated. Nuclei were digested with increasing amounts of DN ase I, and DNA was purified, cut with $\mathrm{N}$ col, and analyzed by Southern blotting. The DNA in lane 8 was digested with $\mathrm{Ncol}$ and Apal to mark the position of fp 1-3 (arrow, A pal-N col). The repeat band of the mutant reporter transgene is indicated by an arrow ( $\mathrm{Ncol}$ ); the hypersensitive site at mutant fp 1-3 by a bracket (HS). (Bottom) The blot was stripped and rehybridized with a probe detecting an $0.85-\mathrm{kb} \mathrm{N}$ col fragment of the mouse $\alpha_{1}$-gl obin gene $(\mathrm{m}-\alpha)$. (C) Quantitation of the hypersensitive site by Phosphorlmager analysis. The signal in the hypersensitive site was divided by the signal in the corresponding mouse $\alpha_{1}$-globin band [(y-axis) relative intensity of the hypersensitive site] and pl otted against the lane number (x-axis). (0) Mutant reporter; ( $\boldsymbol{\square})$ mutant reporter plus mEKLF-pEV.

data that direct binding of EKLF is implicated in the chromatin remodeling activity of $5^{\prime} \mathrm{HS} 3$ of the $\beta$-globin LCR (Ellis et al. 1996).

\section{Discussion}

\section{Binary transgenic systems}

In this paper we have used binary transgenic mice to investi gate the apparent redundancy of transcription factors binding to an important genetic el ement, 5' HS3 of the $\beta$-globin LCR. Our approach encompasses the use of engi neered zinc finger transcription factors rational ly designed to recognize a mutated binding site in 5'HS3. Several binary systems for regulating gene expression have been described, for instance, the yeast GAL4/UAS, the bacterial tet-repressor/operator, and steroid-inducible systems (Ornitz et al. 1991; Gossen et al. 1995; No et al. 1996; Wang et al . 1997). Furthermore, an engineered zinc finger domain recognizing a unique region of the BCR$A B L$ fusion oncogene has been shown to impair the expression of this oncogene in transformed cells after transient transfection in culture (Choo et al. 1994). Our data show that engi neered zinc finger transcription factors are particularly useful tools for the study of tissue-specific activation of gene expression in transgenic mice.

\section{Transcription factors with altered binding specificities}

Previously, it has been shown that the DNA-binding specificity of the Drosophila fushi tarazu (ftz) protein can be altered by changing a single amino acid in its homeodomain. This was used to demonstrate direct autoregulation through binding of the ftz mutant to mutant DN A target sites in a regulatory el ement of the ftz gene, establishing that this in vivo approach can be used to distinguish between activities of homeodomain proteins with very similar binding site specificities (Schier and Gehring 1992). M ost transcription factors are members of families classified by highly conserved DNAbinding domains. Members of such families recognize very similar or even identical DNA sequences and are often found in the same cell types. This suggests that family members may have overlapping arrays of target genes, and in many cases it has proved impossible to show which factor activates which gene. 5' HS3 of the $\beta$-globin LCR is a good example of this problem. The core fragment contains three GATA footprints interspersed by three footprints over $\mathrm{G}$ boxes; fp 1-3 of the core are minimally required for activity in transgenic mice (Philipsen et al. 1990, 1993). Because GATA-1 is the only GATA family member present at late stages of erythroid differentiation, point mutagenesis and in vivo footprinting analyses have demonstrated convincingly that GATA-1 interacts with the GATA sites of $\mathrm{fp} 1$ and 3 in vivo (Strauss and Orkin 1992; Philipsen et al. 1993). In contrast, the $\mathrm{G}$ boxes of fp 2 are bound in vitro by a number of different proteins belonging to the Spl family (Philipsen et al. 1990, 1993). These proteins have very similar binding sites, and no mutations specific for individual factors could be made (Philipsen et al. 1993). To resolve this issue, we have introduced compensatory mutations in the zinc finger domains of the Spl family members Sp1 and EKLF designed to interact with a mutated $\mathrm{G}$ box in fp 2 . Our data show that mEKLF activates 
the mutated 5'HS3 fragment in binary transgenic mice by binding directly to the fp 2 mutant in vivo. In contrast, mSpl does not act as an activator in this context, even though it interacts specifical ly with the fp 2 mutant in vitro and is a functional transactivator through this binding site in the context of the promoter of the OVEC vector. We conclude that specific properties of EKLF are required for activation of $5^{\prime} \mathrm{HS} 3$. Our data do not rule out that other factors are al so capable of activating 5'HS3. Possible candidates are other Spl family members such as BKLF and Sp3 (Hagen et al. 1992; Crossl ey et al . 1996), or the recently described multitype zinc finger protein Friend of GATA-1 (T sang et al. 1997). It remains possi ble that such proteins function as activators of $5^{\prime} \mathrm{HS} 3$ through direct interaction with the wild-type fp 2 sequence. Furthermore, the reporter genes are present as multicopy concatemers, and thus synergism among the multiple insertions might occur. Therefore, it will be of interest to test the activity of mutant binding sites/mutant transcription factor combinations in the structural context of single copy integrants of the complete human $\beta$-globin locus (Strouboulis et al. 1992).

It is likely that replacement of fp 2 with a completely artificial binding site will have a stronger effect on the remaining activity of fp 1-3 (Philipsen et al. 1993). The construction of novel zinc finger domains recognizing the artificial site would be required to activate such a mutant reporter gene. Recently, it has been shown that the specificity of zinc finger domains can be changed efficiently by successive rounds of affinity selection through randomization of the recognition helix of each finger (Greisman and Pabo 1997). Thus, a second generation of mutant Spl family members could be designed that interacts with a completely arbitrary sequence in fp 2 , resulting in more stringent activator/reporter combinations.

\section{EKLF and activation of the $\beta$-globin locus}

In this paper we have used binary transgenic mice to show that EKLF is an activator of the LCR that binds directly to fp 2 of $5^{\prime} \mathrm{HS} 3$. EKLF appears to function in a specific combination with GATA-1 bound at $\mathrm{fp} 1$ and 3 , consistent with earlier results obtained with point mutations and del etions in 5'HS3 (Philipsen et al . 1993; Pruzina et al. 1994). Thus, we have identified an in vivo binding site for EKLF in the $\beta$-globin LCR.

Targeted inactivation of the EKLF gene in mice results in lethality around E14-15 caused by severe anemia due to failure to express the $\beta$-gl obin gene at appropriate levels (N uez et al. 1995; Perkins et al. 1995). The expression of other erythroid-specific genes examined, incl uding the $\alpha$-like and the embryonic/fetal $\beta$-like globins, is not affected showing that EKLF is essential for the activation of the adult $\beta$-globin promoter ( $\mathrm{N}$ uez et al. 1995; Perkins et al. 1995; Wijgerde et al. 1996). In addition, we have demonstrated recently that the expression of 5'HS3IacZ transgenes requires EKLF (T ewari et al. 1998), and DN ase I hypersensitive site analysis of the human $\beta$ globin locus in the EKLF null background showed strongly reduced sensitivity at the $\beta$-globin promoter and moderately reduced sensitivity at 5' HS3 (Wijgerde et al. 1996). These data agree wel I with our observation that direct binding of mEKLF to the mutant fp 1-3 sequence results in elevated reporter gene expression and increased DN ase I hypersensitivity at $\mathrm{fp} 1-3$. We conclude that direct binding of EKLF is implicated in chromatin remodeling over 5'HS3, the only LCR fragment that appears to have an intrinsic dominant chromatin opening activity (Ellis et al. 1996).

Deletion of 5'HS3 in the human or the mouse locus does not inactivate the LCR completely (Hug et al. 1996; Milot et al. 1996b). Deletion of 5'HS3 in the endogenous mouse locus results in a 30\% reduction of $\beta$ gene expression in adult mice (Hug et al. 1996). Natural mutations in the CACC box of the $\beta$-globin promoter result in a less severe reduction of $\beta$ gene expression than observed in EKLF knockout mice (Thein 1993; Perkins et al. 1996; Wijgerde et al. 1996). Thus, it appears that EKLF sites are necessary in both the promoter and the LCR and that these sites act independently of each other. Remarkably, these interactions occur in a different context of other factors, and it is of interest to note that EKLF is not required for the activation of the $\gamma$-globin promoter in fetal liver cells, whereas it is essential for $\beta$-globin promoter activity in the same cells (Perkins et al. 1996; Wijgerde et al. 1996). Thus, we suggest that direct binding of EKLF to both the LCR and the $\beta$ promoter is mandatory for high level transcription of the adult $\beta$-globin gene.

\section{Outlook}

Direct binding of EKLF appears to be pivotal for the function of $5^{\prime} \mathrm{HS} 3$ and the $\beta$-globin promoter. Therefore, mutation of both elements should result in a reporter gene that is expressed at extremely low levels in the absence of the appropriate mEKLF. Rendering mEKLF steroid dependent by fusing it to a steroid-receptor ligand binding domain would give an additional level of control to study the kinetics of gene activation in erythroid cells. The feasibility of steroid-inducible target gene expression in bi nary transgenic mice has been demonstrated (Wang et al. 1997). Inducible activation of LCR-dependent gene expression provides an in vivo system that can be used to address different aspects of gene expression, for instance, recruitment of RNA polymerase II to the promoter, interactions between the LCR and the promoter through DN A looping, and the potential link between transcriptional activation and DNA replication (for review, see Milot et al. 1996a; Ptashne and Gann 1997). We are currently exploring these issues in the context of the complete human $\beta$-globin locus (Strouboulis et al. 1992).

\section{Materials and methooks}

\section{DNA constructs and transgenesis}

Mutations were introduced in the fp 1-3 region of $5^{\prime} \mathrm{HS} 3$ as described (Philipsen et al. 1993), and linked to the Hpal-EcoRV 
fragment of the human $\beta$-gl obin gene. The microinjection fragments were released from vector sequences by digestion with EcoRV, gel purified and used for transgenesis (Kollias et al. 1986). Founder transgenics were either dissected at E13.5 (Philipsen et al. 1990, 1993; Tal bot et al . 1989) or bred to obtain lines. Intactness, mosaicism, and copy numbers of the transgenes were analyzed by Southern blotting (Philipsen et al. 1993).

To change the binding specificity of fingers 1 and 3 of EKLF and Spl, the amino acid substitutions indicated in Figure 2A were introduced by PCR-mediated mutagenesis; the sequence of the cloned PCR products was verified by dideoxy sequencing (Sambrook et al. 1989); the mutated proteins were designated mEKLF and mSpl. For transfection experiments in $\mathrm{CHO}$ cells, cDNAs encoding Spl, mSpl, and mEKLF were cloned in the Notl site of the expression vector pRc/CMV (Invitrogen). Control and mutant binding sites were cloned in the Sall site of the OVEC vector (Westin et al. 1987). The integrity and orientation of the cloned oligonucleotides was determined by dideoxy sequencing. For erythroid-specific expression, the EKLF, mEKLF, Spl, and mSpl cDNAs were cloned in the vector pEV3 (N eedham et al. 1992), resulting in EKLF-pEV, mEKLF-pEV, Sp1-pEV, and mSp1-pEV. Microinjection fragments for transgenesis were obtained by digestion with Aatll and Asp718.

\section{Cell transfections}

$\mathrm{CHO}$ cells $\left(0.5 \times 10^{6}\right)$ were transfected using the cal cium phosphate precipitation method (Graham and Van der Eb 1973) with $3 \mu \mathrm{g}$ of OVEC test vector, $0.15 \mu \mathrm{g}$ of OVEC-REF vector, and 0.1 , 0.5 , or $2 \mu \mathrm{g}$ of the appropriate $\mathrm{pRc} / \mathrm{CMV}$ expression vector, supplemented with pTZ to a total amount of $18 \mu \mathrm{g}$ of DNA. The cells were harvested after $72 \mathrm{hr}$ and used to prepare RNA (Antoniou 1991).

MEL cells $\left(25 \times 10^{6}\right)$ were transfected by electroporation with $25 \mu \mathrm{g}$ of pEV3 derivatives linearized with Scal. After selection for G418 resistance, erythroid differentiation was induced by the addition of dimethylsulfoxide $(2 \% \mathrm{vol} / \mathrm{vol})$ to the media (Antoniou 1991). After 4 days of induction, the cells were harvested and protein extracts were made according to Scholer et al. (1989).

\section{Fetal liver protein and RNA samples}

Fetal livers were dissected from E13.5 fetuses and frozen immediately in liquid nitrogen. RN A was isolated from frozen tissue samples as described (Antoniou 1991; Philipsen et al. 1993). Protein was extracted according to Scholer et al. (1989) and stored at $-80^{\circ} \mathrm{C}$. Western blotting was performed as described, using $20 \mu \mathrm{g}$ of protein per lane (Marin et al. 1997). Rabbit polyclonal antibodies recognizing EKLF and Spl were used in 1:3000 and 1:1000 dilutions, respectively. As a loading control, the blots were reprobed with a rat monoclonal antibody directed against GATA-1 (N 6, cat. no. sc-265, Santa Cruz Biotechnology) used at $3 \mathrm{ng} / \mu \mathrm{l}$.

Expression of the human $\beta$-gl obin transgene was quantitated by $\mathrm{S} 1$ nuclease analysis, using a probe specific for human $\beta$ globin mRNA, and probes detecting mouse $\beta$-major or mouse $\alpha$-globin mRN A as the internal control (Antoniou 1991; Philipsen et al. 1993).

\section{Gel retardation analysis}

Oligonucl eotide probes covering fp 2 were label ed and anneal ed according to Wall et al. (1988). Double-stranded competitor oligonucl eotides were added at the amounts indicated prior to the addition of extract to the reactions. Polyclonal antibodies rec- ognizing Sp1, Sp3, and EKLF were used at 1:160, 1:320, and 1:40 dilutions in the binding reactions, respectively. Incubation was for $30 \mathrm{~min}$ at room temperature. The samples were loaded on $4 \%$ polyacrylamide (PAA) $/ 0.5 \times$ TBE gels and run at $300 \mathrm{~V}$ for 3 $\mathrm{hr}$ at $4^{\circ} \mathrm{C}$. Other details are described in Wall et al. (1988). The sequences of the oligonucleotides used are as follows (only the sense strand is shown): fp 2 control, 5'-AGGTTCCAGTGAGTTTGGGGTGGGGTCAGTG-3'; fp 2 mutant, 5'-A $\bar{G}$ GTTCCAGTGAGTTTGTGGTGGTGTCAGTG-3'; and Spl, 5'-ATAGTCCCGCCCCTAACTCCGCCCAT-3'. Bases different from the wild-type sequence of $\mathrm{fp} 2$ are underlined; bases different between control fp 2 and mutant fp 2 are underlined and in boldface type.

\section{Primary transcript in situ hybridization}

E13.5 livers from individual fetuses were disrupted in $150 \mu \mathrm{l}$ of PBS. Twenty microliters of this cell suspension was spotted onto a polylysine-coated slide and fixed in $4 \%$ formaldehyde, $5 \%$ acetic acid, for $20 \mathrm{~min}$ at room temperature. The slides were then washed three times for $10 \mathrm{~min}$ in PBS and stored in $70 \%$ ethanol at $-20^{\circ} \mathrm{C}$. Two sets of probes were used for in situ hybridization. Four biotinylated oligonucleotides were used to detect human $\beta$-globin transcription. This probe mixture is directed against intron 1; two of the oligonucleotides overlap partially with exon sequences and thus cytoplasmic $\beta$-globin mRN A can also be detected (Dillon et al. 1997). Three DIGlabeled mouse $\alpha$-globin intron-specific oligonucleotides were used to reveal the erythroid cells (Tewari et al. 1996). Hybridizations were done as described by Tewari et al. (1996) and Wijgerde et al. (1995). For antibody detection, the Tyramid amplification system of Dupont N EN was used (Raap et al. 1995). For quantitation, at least 300 cells were scored for each slide. The reproducibility of these data fell within a $10 \%$ error margin.

The following oligonucleotides were used for in situ hybridizations: Human $\beta$-globin, 5'-CTGTCTCCACATGCCCAGTTTCTATGGTCTCCTTAAACCTGTCTTGTAA-3', 5' -GGGTGGGAAAATAGACCAAAGGCAGAGAGAGTCAGTGCCTATCAGAAAC-3', 5'-AGGGCAGTAACGGCAGACTCTCCTCAGGAGTCAGGT-3', and 5'-ATAACAGCATCAGGAGGGACAGATCCCCAAAGGACTCA-3'; M ouse $\alpha$-gl obin, 5'-CACAGAAAAGCATAGTTAGAAGCGCCCACTGAGCGAGTGCCAGGTCC-3', 5'-AGCCCTTCCTAGGGGCCCAGATGCCGCCTGCCAGGTCCC-3', and 5'-GCTCCCCTTCCTGGGACCACTATGTCCCTGCCTTGGGCACGAGGACCC-3'.

\section{DNase I hypersensitivity assay}

Ten E13.5 livers were used to isolate nuclei followed by treatment with increasing amounts of DN ase $I$ at $37^{\circ} \mathrm{C}$ (Ellis et al. 1996). DNA was purified, digested with $\mathrm{Ncol}$, and Southern blotted. A $0.44-\mathrm{kb} \mathrm{H}$ pal-Accl fragment from the $\beta$-gl obin promoter was used as a probe to detect the hypersensitive site at $\mathrm{fp}$ 1-3. A 0.6-kb BamHI-Sacl fragment of the mouse $\alpha_{1}$ globin gene, detecting a $0.85-\mathrm{kb} \mathrm{N}$ col fragment, was used as a control probe. Quantitation was done on a Phosphorlmager with ImageQuant software (M olecular Dynamics).

\section{Acknowledgments}

We thank Drs. Jim Kadonaga, Jim Bieker, and Guntram Suske for the gift of Sp1 cDNA and EKLF and Sp1/Sp3 antibodies, respectively. We are indebted to Dr. Albert Brinkman and Cor Berrevoets for help with the transfection assays. R.T., F.L. and M.W. were supported by a N etherlands Organisatie voor Weten- 
schappelijk Orderzoek (The N etherlands) grant to F.G. T.dW. was supported by Therexsys (UK).

The publication costs of this article were defrayed in part by payment of page charges. This article must therefore be hereby marked 'advertisement' in accordance with 18 USC section 1734 solely to indicate this fact

\section{References}

Anderson, K.P., C.B. Kern, S.C. Crable, and J.B. Lingrel. 1995. Isolation of a gene encoding a functional zinc finger protein homologous to erythroid Kruppel-like factor: Identification of a new multigene family. Mol. Cell. Biol. 15: 5957-5965.

Antoniou, M. 1991. Induction of erythroid-specific expression in murine erythroleukemia (MEL) cell lines. Methods Mol. Biol. 7: 421-434.

Choo, Y. and A. Klug. 1993. A role in DNA binding for the linker sequences of the first three zinc fingers of TFIIIA. Nucleic Acids Res. 21: 3341-3346.

Choo, Y., I. Sanchez-Garcia, and A. Klug. 1994. In vivo repression by a site-specific DN A-binding protein designed against an oncogenic sequence. Nature 372: 642-645.

Crossley, M., E. Whitelaw, A. Perkins, G. Williams, Y. Fujiwara, and S.H. Orkin. 1996. Isolation and characterization of the cDNA encoding BKLF/TEF-2, a major CACCC-box-binding protein in erythroid cells and selected other cells. Mol. Cell. Biol. 16: 1695-1705.

Desjarlais, J.R. and J.M. Berg. 1993. U se of a zinc-finger consensus sequence framework and specificity rules to design spe cific DNA binding proteins. Proc. Natl. Acad. Sci. 90: 22562260.

Dillon, N., T. Trimborn, J. Strouboulis, P. Fraser, and F. Grosveld. 1997. The effect of distance on long-range chromatin interactions. Mol. Cell 1: 131-139.

Ellis, J., K.C. Tanun, A. Harper, D. M ichal ovich, N. Yannoutsos, S. Philipsen, and F. Grosveld. 1996. A dominant chromatinopening activity in $5^{\prime}$ hypersensitive site 3 of the human $\beta$-globin locus control region. EMBO J. 15: 562-568.

Feng, W.C., C.M. Southwood, and J.J. Bieker. 1994. Analyses of $\beta$-thalassemia mutant DNA interactions with erythroid Kruppel-like factor (EKLF), an erythroid cell-specific transcription factor. J. Biol. Chem. 269: 1493-1500.

Fraser, P., J. Hurst, P. Collis, and F. Grosveld. 1990. DN ase I hypersensitive sites 1,2 and 3 of the human $\beta$-globin dominant control region direct position-independent expression. Nucleic Acids Res. 18: 3503-3508.

Gossen, M., S. Freundlieb, G. Bender, G. Muller, W. Hillen, and H. Bujard. 1995. Transcriptional activation by tetracyclines in mammalian cells. Science 268: 1766-1769.

Graham, F.L. and A.J van der Eb. 1973. A new technique for the assay of infectivity of human adenovirus 5 DNA. Virology 52: 456-467.

Greisman, H.A. and C.O. Pabo. 1997. A general strategy for selecting high-affinity zinc finger proteins for diverse DNA target sites. Science 275: 657-661.

Grosveld, F., N. Dillon, and D. Higgs. 1993. The regulation of human globin gene expression. Bailliere's Clin. Hematol. 6: 31-55.

Hagen, G., S. Muller, M. Beato, and G. Suske. 1992. Cloning by recognition site screening of two novel GT box binding proteins: a family of Spl related genes. Nucleic Acids Res. 20: 5519-5525.

- - . 1994. Spl-mediated transcriptional activation is re pressed by Sp3. EMBO J. 13: 3843-3851.

Hug, B.A., R.L. Wesselschmidt, S. Fiering, M.A. Bender, E. Epner, M. Groudine, and T.J. Ley. 1996. Analysis of mice containing a targeted deletion of $\beta$-globin locus control region 5' hypersensitive site 3. Mol. Cell. Biol. 16: 2906-2912. Imataka, H., K. Sogawa, K. Y asumoto, Y. Kikuchi, K. Sasano, A. Kobayashi, M. Hayami, and Y. Fujii-Kuriyama. 1992. Two regulatory proteins that bind to the basic transcription element (BTE), a GC box sequence in the promoter region of the rat P-4501A 1 gene. EMBO J. 11: 3663-3671.

Isalan, M., Y. Choo, and A. Klug. 1997. Synergy between adjacent zinc fingers in sequence-specific DNA recognition. Proc. Natl. Acad. Sci. 94: 5617-5621.

Jacobs, G.H. 1992. Determination of the base recognition positions of zinc fingers from sequence analysis. EMBO J. 11: 4507-4517.

Kadonaga, J.T., K.R. Carner, F.R. M asiarz, and R. Tjian. 1987. Isolation of CDNA encoding transcription factor Sp1 and functional analysis of the DNA binding domain. Cell 51: 1079-1090.

Kingsley, C. and A. Winoto. 1992. Cloning of GT box-binding proteins: A novel $\mathrm{Spl}$ multigene family regulating $\mathrm{T}$-cell receptor gene expression. Mol. Cell. Biol. 12: 4251-4261.

Kollias, G., N. Wrighton, J. Hurst, and F. Grosveld. 1986. Regulated expression of human A $\gamma^{-}, \beta-$, and hybrid $\gamma \beta$-globin genes in transgenic mice: manipulation of the developmental expression patterns. Cell 46: 89-94.

Letovsky, J. and W.S. Dynan. 1989. M easurement of the binding of transcription factor $\mathrm{Spl}$ to a single GC box recognition sequence. Nucleic Acids Res. 17: 2639-2653.

Li, R., J.D. Knight, S.P. Jackson, R. Tjian, and M.R. Botchan. 1991. Direct interaction between Spl and the BPV enhancer E2 protein mediates synergistic activation of transcription. Cell 65: 493-505.

Marin, M., A. Karis, P. Visser, F. Grosveld, and S. Philipsen. 1997. Transcription factor Spl is essential for early embryonic development but dispensable for cell growth and differentiation. Cell 89: 619-628.

M erika, M. and S.H. Orkin. 1995. Functional synergy and physical interactions of the erythroid transcription factor GATA-1 with the Kruppel family proteins Spl and EKLF. Mol. Cell. Biol. 15: 2437-2447.

Miller, I.J. and J.J. Bieker. 1993. A novel, erythroid cell-specific murine transcription factor that binds to the CACCC ele ment and is related to the Kruppel family of nuclear proteins. Mol. Cell. Biol. 13: 2776-2786.

Milot, E., P. Fraser, and F. Grosveld. 1996a. Position effects and genetic disease. Trends Genet. 12: 123-126.

Milot, E., J. Strouboulis, T. Trimborn, M. Wijgerde, E. Deboer, A. Langeveld, K. Tanun, W. Vergeer, N. Yannoutsos, F. Grosveld, and P. Fraser. 1996b. Heterochromatin effects on the frequency and duration of LCR-mediated gene transcription. Cell 87: 105-114.

N arayan, V.A., R.W. Kriwacki, and J.P. Caradonna. 1997. Structures of zinc finger domains from transcription factor Spl. Insights into sequence-specific protein-DNA recognition. J. Biol. Chem. 272: 7801-7809.

Needham, M., C. Gooding, K. Hudson, M. Antoniou, F. Grosveld, and M. Hollis. 1992. LCR/MEL: A versatile system for high-level expression of heterologous proteins in erythroid cells. Nucleic Acids Res. 20: 997-1003.

No, D., T.P. Yao, and R.M. Evans. 1996. Ecdysone-inducible gene expression in mammalian cells and transgenic mice. Proc. Natl. Acad. Sci. 93: 3346-3351.

Nuez, B., D. Michalovich, A. Bygrave, R. Ploemacher, and F. Grosveld. 1995. Defective haematopoiesis in fetal liver re sulting from inactivation of the EKLF gene. Nature 375: 316318.

Ornitz, D.M., R.W. Moreadith, and P. Leder. 1991. Binary sys- 
tem for regulating transgene expression in mice: Targeting int-2 gene expression with yeast GAL4/UAS control elements. Proc. Natl. Acad. Sci. 88: 698-702.

Pavletich, N.P. and C.O. Pabo. 1991. Zinc finger-DN A recognition: crystal structure of a Zif268-DNA complex at $2.1 \mathrm{~A}$. Science 252: 809-817.

Perkins, N.D., A.B. Agranoff, E. Pascal, and G.J. N abel. 1994. An interaction between the DN A-binding domains of RelA (p65) and Sp1 mediates human immunodeficiency virus gene activation. Mol. Cell. Biol. 14: 6570-6583.

Perkins, A.C., A.H. Sharpe, and S.H. Orkin. 1995. Lethal $\beta-$ thalassaemia in mice lacking the erythroid CACCC-transcription factor EKLF. Nature 375: 318-322.

Perkins, A.C., K.M. Gaensler, and S.H. Orkin. 1996. Silencing of human fetal globin expression is impaired in the absence of the adult $\beta$-globin gene activator protein EKLF. Proc. Natl. Acad. Sci. 93: 12267-12271.

Philipsen, S., D. Talbot, P. Fraser, and F. Grosveld. 1990. The $\beta$-globin dominant control region: Hypersensitive site 2. EMBO J. 9: 2159-2167.

Philipsen, S., S. Pruzina, and F. Grosveld. 1993. The minimal requirements for activity in transgenic mice of hypersensitive site 3 of the $\beta$ globin locus control region. EMBO J. 12: 1077-1085.

Pruzina, S., M. Antoniou, J. Hurst, F. Grosveld, and S. Philipsen. 1994. Transcriptional activation by hypersensitive site three of the human $\beta$-globin locus control region in murine erythroleukemia cells. Biochim. Biophys. Acta 1219: 351-360.

Ptashne, M. and A. Gann. 1997. Transcriptional activation by recruitment. Nature 386: 569-577.

Raap, A.K., M.P. van de Corput, R.A. Vervenne, R.P. van Gijlswijk, H.J. Tanke, and J. Wiegant. 1995. Ultra-sensitive FISH using peroxidase-mediated deposition of biotin- or fluorochrome tyramides. Hum. Mol. Genet. 4: 529-534.

Sambrook, J., E.F. Fritsch, and T. Maniatis. 1989. Molecular cloning: A laboratory manual. Cold Spring Harbor Laboratory Press, Cold Spring Harbor, NY.

Schier, A.F. and W.J. Gehring. 1992. Direct homeodomain-DN A interaction in the autoregulation of the fushi tarazu gene. Nature 356: 804-807.

Scholer, H.R., R. Balling, A.K. Hatzopoulos, N. Suzuki, and P. Gruss. 1989. Octamer binding proteins confer transcriptional activity in early mouse embryogenesis. EMBO J. 8: 2551-2557.

Shields, J.M., R.J. Christy, and V.W. Yang. 1996. Identification and characterization of a gene encoding a gut-enriched Kruppel-like factor expressed during growth arrest. J. Biol. Chem. 271: 20009-20017.

Sjottem, E., C. Andersen, and T. Johansen. 1997. Structural and functional analyses of DNA bending induced by Sp1 family transcription factors. J. Mol. Biol. 267: 490-504.

Strauss, E.C. and S.H. Orkin. 1992. In vivo protein-DNA interactions at hypersensitive site 3 of the human $\beta$-gl obin locus control region. Proc. Natl. Acad. Sci. 89: 5809-5813.

Strouboulis, J., N. Dillon, and F. Grosveld. 1992. Developmental regulation of a complete 70-kb human $\beta$-globin locus in transgenic mice. Genes \& Dev. 6: 1857-1864.

Talbot, D., P. Collis, M. Antoniou, M. Vidal, F. Grosveld, and D.R. Greaves. 1989. A dominant control region from the human $\beta$-globin locus conferring integration site-independent gene expression. Nature 338: 352-355.

Tewari, R., N. Gillemans, A. Harper, M. Wijgerde, G. Zafarana, D. Drabek, F. Grosveld, and S. Philipsen. 1996. The human $\beta$-globin locus control region confers an early embryonic erythroid-specific expression pattern to a basic promoter driving the bacterial lacZ gene. Devel opment 122: 3991-3999.
Tewari, R., N. Gillemans, M. Wijgerde, B. Nuez, M. von Lindern, F. Grosveld, and S. Philipsen. 1998. Erythroid Krüppel-like factor (EKLF) is active in primitive and definitive erythroid cells and is required for the function of 5' HS3 of the $\beta$-gl obin locus control region. EMBO J. 17: 2334-2341.

Thein, S.L. 1993. $\beta$-thal assaemia. Bailliere's Clin. Hematol. 6: 151-175.

Tsang, A.P., J.E. Visvader, C.A. Turner, Y. Fujiwara, C.N. Yu, M.J. Weiss, M. Crossley, and S.H. Orkin. 1997. FOG, a multitype zinc finger protein, acts as a cofactor for transcription factor GATA-1 in erythroid and megakaryocytic differentiation. Cell 90: 109-119.

Wall, L., E. deBoer, and F. Grosveld. 1988. The human $\beta$-globin gene $3^{\prime}$ enhancer contains multiple binding sites for an erythroid-specific protein. Genes \& Dev. 2: 1089-1100.

Wang, Y.L., F.J. Demayo, S.Y. Tsai, and B.W. Omalley. 1997. Ligand-inducible and liver-specific target gene expression in transgenic mice. Nat. Biotechnol. 15: 239-243.

Westin, G., T. Gerster, M.M. Mueller, G. Schaffner, and W. Schaffner. 1987. OVEC, a versatile system to study transcription in mammalian cells and cell-free extracts. Nucleic Acids Res. 15: 6787-6798.

Wijgerde, M., F. Grosveld, and P. Fraser. 1995. Transcription complex stability and chromatin dynamics in vivo. Nature 377: 209-213.

Wijgerde, M., J. Gribnau, T. Trimborn, B. N uez, S. Philipsen, F. Grosveld, and P. Fraser. 1996. The role of EKLF in human $\beta$-gl obin gene competition. Genes \& Dev. 10: 2894-2902. 


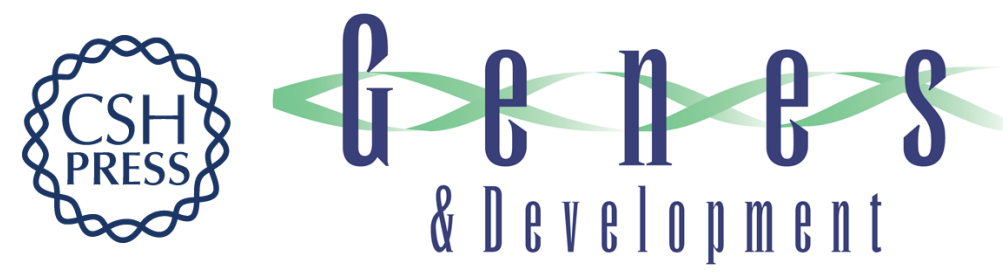

\section{Altered DNA-binding specificity mutants of EKLF and Sp1 show that $E K L F$ is an activator of the $\beta$-globin locus control region in vivo}

Nynke Gillemans, Rita Tewari, Fokke Lindeboom, et al.

Genes Dev. 1998, 12:

Access the most recent version at doi:10.1101/gad.12.18.2863

References

This article cites 60 articles, 24 of which can be accessed free at: http://genesdev.cshlp.org/content/12/18/2863.full.html\#ref-list-1

License

Email Alerting

Receive free email alerts when new articles cite this article - sign up in the box at the top Service right corner of the article or click here.

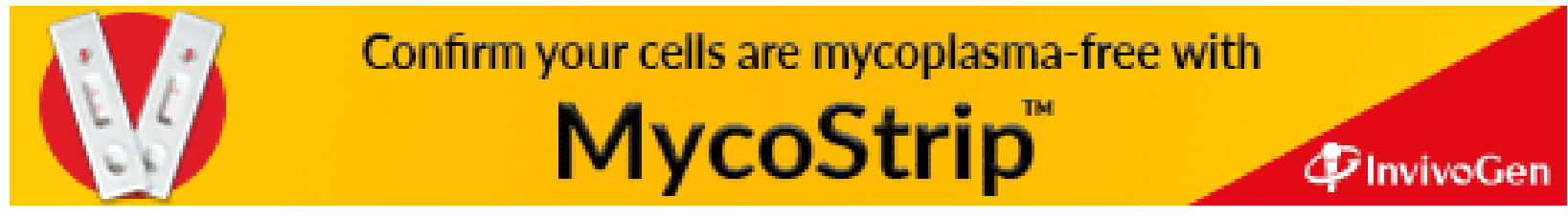

